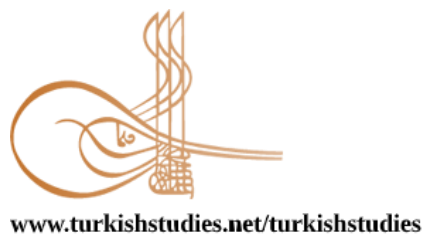

Turkish Studies

\title{
Frengi Hastalığının İzmir'de Ortaya Çıkışı ve Şehirdeki Umumhaneler
}

\author{
The Outbreak of Syphilis Disease and the Brothels in Izmir Province
}

\author{
Ayşen Müderrisoğlu Esiner ${ }^{*}$ - Simge Sarçın**
}

\begin{abstract}
Epidemics have ravaged humanity throughout its existence, sometimes changing the course of history. As a kind of a natural disaster have affected almost millions of people in social, demographic, economic and political areas throughout history. Epidemics that have a great destruction all over the world, also affected the territories of the Ottoman State. Plague, cholera, typhus, variola, trachoma tuberculosis and syphilis are some of the examples of epidemics. In this respect, there was an increase in the rates of the epidemics in parallel to the rise in people's mobilization over the world due to the technological advances in the transportation network in the nineteenth century. Ottoman State was also under the effect of this mobilization and so there was an important increase in the numbers of people coming to the territories of the empire. As one of the consequences of it, the spread of epidemics became easier in contrast to the past. In this context, İzmir as a significant port city of the Ottoman State highly suffered from the syphilis. In 1889, the disease first appeared in the city because of the increased prostitution. Due to the brothels shown as a main actor in the spread of it, the government attempted to prevent it by making some legal regulations. In this research, syphilis as one of the most important venereal diseases and its outbreak in the Ottoman State, and the following process will be touched after informing about the disease. Yet, the main purpose of the study is to examine the syphilis' appearance and the measures and the struggle with the disease in İzmir province between the last decades in the nineteenth century and the beginning of the twentieth century. It aims to find answer the causes of the outbreak of the disease by examining the role of prostitution and the brothels in İzmir. Also, the approaches of the government to the disease and its measures to prevent it in the province will be studied in this research.
\end{abstract}

Structured Abstract: Epidemics have ravaged humanity throughout its existence, sometimes changing the course of history. As a kind of a natural disaster have affected almost millions of people in social, demographic, economic and political areas throughout history. Epidemics that have a great destruction all over the world, also affected the territories of the Ottoman State. Plague, cholera, typhus, variola, trachoma, tuberculosis and syphilis are some of the examples of epidemics. In the nineteenth century, there was an increase in the rates of the epidemics in parallel to the rise in people's mobilization over the world due to the technological advances in the transportation network. Ottoman State was also under the effect of this mobilization, there was an

\footnotetext{
${ }^{*}$ Dr. Öğr. Üyesi, Yeditepe Üniversitesi, Fen-Edebiyat Fakültesi, Tarih Bölümü Asst.Prof, Yeditepe University, Faculty of Science and Literature, Department of History

ORCID 0000-0001-8873-4225

aysen.muderrisoglu@yeditepe.edu.tr

** Doktora Öğrencisi, Yeditepe Üniversitesi, Fen-Edebiyat Fakültesi, Tarih Bölümü

PhD student, Yeditepe University, Faculty of Science and Literature, Department of History

ORCID 0000-0003-3460-3726

simgesarcin1@gmail.com

Cite as/ Atıf: Müderrisoğlu Esiner, A., Sarçın, S. (2020). Frengi hastalığının İzmir'de ortaya çıkışı ve şehirdeki umumhaneler. Turkish Studies, 15(4), 753-763. https://dx.doi.org/10.7827/TurkishStudies.43822

Received/Geliş: 28 May/Mayıs 2020

Accepted/Kabul: 10 August/Ağustos 2020

Copyright $(\mathrm{C}$ MDE, Turkey
} 
important increase in the numbers of people coming to the territories of the empire. As one of the consequences of it, the spread of epidemics became easier in contrast to the past.

Syphilis, called as "frengi", which is the subject of our research, was observed for the first time in the Ottoman geography during the nineteenth century. While the disease mostly transmitted sexually, it can pass from mother to child during pregnancy. The outbreak and the rising periods of the disease in the Ottoman State recorded as following years which coincided with mostly the war times as 1806-1812, 1828-1829, 1854-1856 and 1877-1878 Ottoman-Russian War. The struggle with syphilis first began in İstanbul, the capital city of the Ottoman State. Subsequently, the disease was observed in Kastamonu, Sivas, Hüdavendigar, Erzurum, İzmir, Edirne, Jerusalem, Gazze, Yanya, Thessaloniki and Baghdad. Increasing prostitution activities were shown as the main cause of the spread of it. For this reason, the government allowed the opening of the first brothel in 1856-1858 to take prostitution under control. Therefore, the first brothel was located Galata, Beyoğlu in İstanbul. One of the most significant attempts to prevent the spread of the disease was the declaration of a new regulation concerning prostitution. While this regulation revealed the extent of the problem, it also provided for increased official recognition of brothels. The government issued a detailed regulation on prostitution which was called as "The Regulation on the Prevention of the Spread of Venereal Disease". This new regulation embraced all the provincial areas and defined the legal framework through detailed prescriptions. Its main purpose was certainly to control the spread of venereal diseases. To achieve it, the regulation attempted to subject brothels to stricter state control and register prostitutes while keeping them under the medical surveillance. In addition, a variety of fines and punishments were issued for those who violated the regulatory measures.

The Ottoman State, on the other hand, encountered to the severe wartime conditions led to an increase in prostitution due to the famine and poverty during the World War I. As a result, the government founded some hospitals especially in the cities had high rates of prostitution cases to take increased prostitution under control and prevent the spread of the disease. Moreover, the government began to keep the public opinion informed about the effects of the disease due to the newspapers and various publications in this period. In that process, a new drug called as "606 Salvarsan" which was discovered by Paul Ehrlich, began to be used in the treatment of the disease while mercury, iodine and potassium was being used before it.

İzmir as a significant port city of the Ottoman State highly suffered from the syphilis. In 1889, the disease first appeared in the city because of the increased prostitution. Due to the brothels shown as a main actor in the spread of it, the government attempted to prevent it by making some legal regulations. A Sanitary Commission established by the government prepared an important health report consisted of ten articles to prevent the spread of the disease. The details of this report will be given in this study.

Although various methods were developed to prevent syphilis, the most important decision was the establishment of "Emraz-1 Zühreviye Hastanesi" (Syphilis Hospital) in Tepecik district of İzmir in 1908. Prostitutes had to be examined in this hospital once a week and stayed there until recovery. While the hospital served under the İzmir Municipality when it was founded, it was administered by a special commission after the Administrative Province Law issued in 1913, and the name of the hospital changed as Eşref Pasha Hospital.

One of the important issues reflected in the press regarding syphilis was about the Syphilis Hospital of İzmir. In this context, a newspaper of the period called as "Ahenk", which we used as a source, contained various reports and information about the hospital. The causes of the spread of syphilis, treatment methods and some measures to prevent it were taken place in this newspaper. In this research, syphilis as one of the most important venereal diseases and its outbreak in the Ottoman State, and the following process will be touched. Yet, the main purpose of the study is to examine the syphilis's appearance and the measures, struggle with the disease in İzmir province between the last decades in the nineteenth century and the beginning of the twentieth century. It aims to find answer the causes of the outbreak of the disease by examining the role of prostitution in İzmir. Also, the approach of the government to the disease and its measures to prevent it in this province. In addition, the publications on "Ahenk" and the documents from the Ottoman Archives of Prime Ministry will be used in this research.

Keywords: İzmir, syphilis, epidemics, prostitution, brothels 
Öz: İnsanlığı büyük yıkımlara sürükleyen salgın hastalıklar kimi dönemlerde tarihin seyrini bile değiştirmeye muktedir olmuştur. Tarih boyunca adeta doğal bir felaket olarak kendini gösteren bu hastalıklar milyonlarca insanı toplumsal, demografik, ekonomik ve siyasal alanlarda etkilemiştir. Dünya üzerinde müthiş bir yıkıcı etkisi olan salgın hastalıklardan şüphesiz Osmanlı toprakları da payını almıştır. Veba, kolera, tifüs, çiçek, trahom, tüberküloz ve frengi bu salgınların bir kısmını oluşturmaktadır. On dokuzuncu yüzyılda teknolojik gelişmelere bağlı olarak ulaşım alanında yaşanılan kolaylıklar insanların daha kolay mobilize olmasını sağlarken salgın hastalıkların da yayılmasını etkilemiştir. Osmanlı Devleti de söz konusu mobilizasyonun etkisi altında kalmış ve imparatorluk topraklarına giriş yapan insan sayısında önemli bir artış yaşanmıştır. Bu durumun bir sonucu olarak salgın hastalıklar geçmiş dönemlerin aksine daha fazla yayılmaya başlamıştır. Bu bağlamda Osmanlı Devleti'nin önemli bir liman şehri olan İzmir ise frengi hastalığından son derece muztarip olmuştur. İlk defa 1889'da görülen bu hastalığın en önemli sebebi artan fuhuş faaliyetleridir. Umumhaneler (Genelevler) hastalığın yayılmasında başlıca role sahip olurken, Osmanlı hükümeti bu hususta birtakım önlemler alarak yasal düzenlemeler yapmıştır. Bu çalışmada ise en önemli zührevi hastalıklardan biri olan frenginin Osmanlı Devleti'nde ortaya çıkışı ve müteakip süreç üzerinde durulacaktır. Ancak çalışmamızın esas amacı XIX. yüzyılın sonlarında İzmir'de ilk defa görülen frengi hastalığı ve bu hastalıkla mücadele hususunda alınan önlemleri irdelemektir. Araştırmamız İzmir bölgesindeki fuhuş faaliyetlerinin ve umumhanelerin, hastalığın yayılmasındaki rolünü ortaya koymaya çalışacak ve hükümetin bu hususta aldığı önlemleri inceleyecektir.

Anahtar Kelimeler: İzmir, frengi, salgın hastalık, fuhuş, umumhaneler

\section{Giriş}

Sifilis olarak da bilinen Frengi, Osmanlı hekimleri tarafindan illet-i efrenciye, frenk uyuzu, daü'l-efrenç, maraz-ı efrenciye, zahm-i frenk, riş-i frenk olarak adlandırılmış ve Avrupa menşeli bir illet olarak tanımlanmıştır. Genellikle cinsel yolla bulaşan, insan vücudunda yaralara ve fiziki bozukluklara sebep olan zührevi bir hastalıktır. Bu hastalık cinsel yolun dışında frengi mikrobunu taşıyan bir hamile kadından çocuğuna da geçebilmektedir. Ayrıca kişinin frengi yaralarına doğrudan temas etmesiyle de hastalık bulaşabilmektedir (Çavdar-Karc1, 2016:158).

Frengi hastalığ 1 ilk olarak Amerika'nın keşfedilmesiyle birlikte Avrupa topraklarında görülmeye başlanmıştır. Yapılan bazı araştırmalara göre bu hastalık köle ticaretinin bir sonucu olarak Doğu Afrika'da ortaya çıkmış gibi görünmektedir (Bruce M. Rothschild, 2005: 1454). Afrika'dan Asya'ya yayılmış ve oradan Kuzey Amerika bölgesine geçmiştir. 1497 yılında İsviçre, Fransa ve Almanya'da; 1499 yılında Macaristan ve Rusya' da görülmüştür. Hastalık başka ülkelere Portekizli gemiciler vasıtasıyla götürülürken 1498 yılında Hindistan'da, 1505 yılında Güney Çin'de, 1569'da ise Japonya'da görülmeye başlamıştır.

Osmanlı Devleti'nde ise veba, kolera, tifüs, çiçek, trahom, verem, frengi vb. birçok salgın hastalık görülmüştür. Bilhassa XIX. yüzyılda ulaşımda yaşanılan teknolojik ilerlemelere paralel olarak insanlar daha kolay mobilize olmuş ve farklı coğrafyalardan Osmanlı topraklarına yapılan giriş çıkışlarda artış yaşanmıştır (Esiner, 2018: 445) Önceki yüzyıllara nispeten hızla artan söz konusu mobilizasyon, bulaşıcı hastalıkların yayılmasında önemli bir paya sahiptir. Bulaşıcı hastalıklar arasında öne çıkan Frengi hastalığının da Osmanlı topraklarında ilk defa görülmeye başlaması yine bu yüzyıla denk gelmiştir. Diğer taraftan hastalık 1806-1812, 1828-1829, 1856 ve 1877-78 Osmanlı Rus Savaşı yılları arasında yükselme eğilimine geçmiştir (Hot, 2015:118). Frenginin yoğun görüldüğü şehirler arasında ise Kastamonu, Konya, Maraş, Aydın, Sivas, Hüdavendigar, Erzurum, Edirne, İzmir, Kudüs, Gazze, Yanya, Selanik ve Bağdat yer alırken, Osmanlı Devleti'nde bu hastalıkla mücadele ilk olarak İstanbul'da başlamıştır (Şenel, 2015: 258259).

Frengi hastalığı özellikle 1853-1856 yıllarında gerçekleşen Kırım Savaşı ile artış göstermiştir (Martal, 2000: 89). Bu savaş sebebiyle 1854'te Fransız ve İngiliz askerleri Osmanlı Devleti'nin müttefiki olarak İstanbul'a gelmişler, Fransızlar Avrupa yakasına İngiliz birlikleri ise Anadolu 
yakasına yerleştirilmişlerdir. Osmanlı topraklarında uzun süre ikamet eden bu askerler kendi kültürlerini, eğlencelerini ve yaşam biçimlerini de beraberinde getirmek suretiyle İstanbul halkının zevk ve eğlence hayatını etkilemişlerdir (Özcan, 2003: 109). Yabanc1 milletlerden oluşan bu birliklerin İstanbul'a gelmesiyle birlikte şüphesiz fuhuş faaliyetlerinde artış yaşanmıştır. Yükselişe geçen fuhuş problemine paralel olarak frengi hastalığında da artış yaşanmış ve bu durum karşısında hükümet İstanbul'da çeşitli önlemler almaya başlamıştır. Bu sebeple devletin denetim mekanizmasına girmesi amacıyla 1856 'da şehirdeki ilk genelevin açılmasına izin verilmiş ve bu iş için Gayri-mü̈slìn nüfísun yoğun olarak yaşadığı bölgelerden biri olan Galata bölgesi uygun bulunmuştur (Yıldırım, 1985: 1326). İstanbul'da ilk genelevlerin açılmasını müteakiben diğer Osmanlı şehirlerinde de umumhane işletmeleri açılmaya başlanmış ve giderek yaygınlaşmıştır (Kırlı,

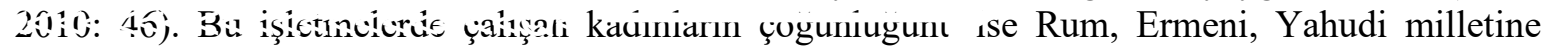
mensup Gayri-müslim kadınlar oluşturmuştur.

Diğger tarafia! is78, j11trda Doktor Michael ile Muallim Dr. Miralay Agop Handanyan Beyoğlu ve Galata'daki genelevlerde çalışan kadınların sağlık kontrolünden geçmeleri ve sürekli teftiş yapılmasının gerekliliği konusunda bir rapor hazırlamışlardır. Hazırlanan rapor sonucunda Emraz-1 Zühreviye Nizamnamesi yürürlüğe girmiştir. Bu nizamnameyle birlikte yeterli sayıda hekim, memur ve belediye çavuşu görevlendirilmiş ve genelevlerin teftişi ile hayat kadınlarının muayenesi yapılmaya başlanmıştır (Yıldırım, 1985:1326). Frengi ile mücadelede alınan bir diğer önlem ise Alman Dermatolog ve Zührevi Hastalıklar Uzmanı Ernest von Düring'in İstanbul'a getirtilerek hastalıkla mücadele hususunda bilgi ve tecrübelerine başvurmak olmuştur. 1889-1902 yılları arasında Düring ile 16 doktor ve 2 eczacının ortak çalışması sonucunda hastalı̆̆ın nasıl önüne geçilebileceği üzerine önemli bir girişim başlatılmıştır. Doktor Düring frengiyle mücadelesine hastalığın yaygın olarak görüldüğü Kastamonu ilinden başlamıştır. Ancak Kastamonu ve Safranbolu'da frengi hastanesi açılmasına rağmen bu illetin önüne geçilememiştir (Ocak,2016: 1516).

Hastalıkla mücadele amacıyla 1908 yılından itibaren İstanbul'da hayat kadınlarının kayıtları tutulmaya başlanmış ve zorunlu tedavileri yapılmıştır. 28 Aralık 1909 tarihinde frengi hastalığının yayılmasını önlemek amacıyla İnzibat-ı Sihhi-i Hususi Nizamnamesi projesi Dâhiliye Nezaretine sunulmuştur. Fakat 1915 yılında dahi söz konusu nizamname yürürlüğe girmemiştir. Bu nedenle nizamname yürürlüğe girinceye kadar tüm Osmanlı şehirlerinde faaliyette bulunan umumhanelerin zabıta tarafindan kontrolü zorunlu kılınmıștır (BOA:1331).

Frengi hastalığının artışında şüphesiz fuhuş oranlarındaki yükseliş en önemli etken olmuştur. Belirttiğimiz üzere savaş dönemleri bu oranlardaki artışın en önemli sebepleri arasındadır. $\mathrm{Bu}$ noktada Birinci Dünya Savaşı yıllarında artan fuhuş faaliyetlerine paralel olarak frengi hastalığında da önemli bir yükselme gözlemlenmiştir. Son derece yıkıcı etkileri olan bu savaşın yarattığı açlık ve sefaletten en çok etkilenenler kadınlar ve çocuklar olmuştur. Erkeklerin silâhaltında bulunmaları sebebiyle kadınlar ailelerinin geçimlerinden sorumlu birinci kişi haline gelmişlerdir. $\mathrm{Bu}$ süreçte yaşanılan ekonomik sıkıntıların yol açtı̆ğ zorluklar neticesinde fuhuşla birlikte salgın hastalıklarda da artış göstermiştir. (Gözcü, 2016:139-140). Ancak erkeklerin savaş sebebiyle farklı cephelere gitmesi ve yaptıkları fuhuş sonucunda ülkelerine geri döndüklerinde salgın hastalıkları arttırmış olmaları kuvvetli bir ihtimaldir. Bu hastalıkların önüne geçebilmek adına şehrin çeşitli yerlerine sağlık kuruluşları açılmış ve kamuoyunu bu hastalık konusunda bilgilendirmek adına önemli yayınlar yapılmıştır.

Osmanlı toplumunu Frengi hastalı̆̆ 1 hakkında bilinçlendirmek için yapılan yayınlardan birisi 1914 tarihli Sağlık Bilgisi isimli çalışmadır. Bu eserde yer alan ifadeler frengi hastalığının toplumda yaratmış olduğu korkuyu da gözler önüne sermesi açıdan önem arz etmektedir. Söz konusu illetin vahameti hakkında şu mühim ifadelere yer verilmiştir: "Frengi pek fena bir hastallktır. Dünyanın her tarafinda vardır. Hele memleketimizde pek çoktur. Vücudun her tarafinda fenalıklar yapar. 
Gözleri kör; elleri, ayakları tutmaz eder; delilik getirir, burnu düşürür... Frengililerin çocukları ekseriyetle düşer veya ölü doğar. Canlı doğanlar da frengili ve birçok yerleri eksik ve alil olur; kansiz, budala, mecnun olurlar... Frengi evlatlara miras kalır bir hastallktır. Torunlara pek geçmezse de onları da cılız ve çelimsiz eder. Frengililerin çocukları ekseriya kusurlu olurlar. Hele dişleri kendilerine mahsus bir biçimdedir... Frengiyi iyi etmek için eskiden beri clva merhemi sürülmektedir. Şimdi bununla beraber başka yeni ilaçlar da kullanıllyor. Herhalde frengiye tutulmamak için fena yollara sapmamalıdır. Hele evli barklı bir adam frengiye tutulursa hastalık, haremine ve çocuklarına geçer; soyu sopu mahvolur... Vatanımız bu illetten pek ziyade inlemektedir. Birçok evler barklar sönmekte ve bu yüzden bazı köyler baştanbaşa frengi içinde mahvolmaktadır; nice insanların bu hastallk sebebiyle nesli kurumuştur. Vereme hazır olanlar bu hastalığa tutulmamaya gayret etmelidir çünkü frengi, veremi adeta körükler... Frengiye yakalananlar evlenmemelidir, çünkü hastalık ailesine sirayet eder. İste frengi böyle murdar, mülevves (pis, kirli) bir hastalıktır; kendimizi ve memleketimizi bu müthiş beladan korumaya çalışalım." (Sağlık Bilgisi, 1330: 45-47'den Ocak, 2016: 15)

Frengi tedavisinde önceleri civa, iyodür ve potasyum kullanılmakta idi. Tedavinin tütsüleme ile yapılması tıbbi açıdan doğru olmamasının yanında insan sağlığını ciddi ölçüde tehdit etmekteydi (Hot, 2015: 122). İlerleyen zamanlarda frengi hastalığında kullanılması için Yahudi asıllı Alman Bilgin Paul Ehrlich ve yardımcısı "606 -Salvarsan" adlı ilacı keşfetmişlerdir (Ocak, 2016: 14). Bulaşıcı ve zührevi hastalıklarla hukuki mücadele noktasında ise 1914 yılında Emraz-ı Sâriye ve Istilaiye (Bulaşıcı ve Yayılan Hastalıklar) ve 1915 yılında ise Emraz-ı Zühreviyenin Men-i Sirayetine Dair (Zührevi Hastalıkların Bulaşmasını Önlemeye İlişkin) isimli nizamnameler yürürlüğe girmiştir (Karayaman, 2008: 177). Ayrıca hastalığın tedavisi için 1914 ve 1916 yıllarında hastane sayıları arttırılmıştır. Söz konusu hastaneler İnebolu, Bartın, Cide, Ayancık, Çankırı, Boyabat, Bolu, Safranbolu ve Ereğli'de açılmıştır. Ayrıca kayıtlara göre seyyar hekimler sayesinde 401 bin kişinin muayenesi yapılmıştır (Hot, 2015: 121). Ancak frenginin yayılmasını önlemek adına alınan tüm önlemlere rağmen hastalık artarak devam etmiştir (Kırlı, 2010: 46).

\section{İzmir'in Coğrafi ve Nüfus Yapısı}

Aydın vilayetinin merkezi olan İzmir XIX. yüzyılda İstanbul'dan sonra Anadolu'nun ikinci büyük şehridir. Şehir batı sahillerinin ortasında İzmir Körfezi içinde yer almaktadır (Şemsettin Sami, 1996: 849-851). İzmir Körfezi, kuzey-güney doğrultusunda geniş başlayan sonrasında az çok buna dik açı oluşturup bitişen, bat1-doğu doğrultusunda ve daha dar bir körfezle sona eren iki parça şeklindedir. Şehrin tehlikelere karşı korunmasını sağlayan bu şekil önemli bir coğrafi faktördür. Çevresinde Hekim Adası, Uzun Ada ve bunların dışında daha birçok adanın bulunması şehre gelebilecek tehlikelerin önceden fark edilmesini sağlamaktadır. Söz konusu bu coğrafi yapı İzmir'e barınmaya elverişli bir liman kenti olma özelliğini kazandırmaktadır (Kütükoğlu, 2006: 515). Kentin bu özelliği, dünyanın her yerinden gelen yabancıların uğrak yeri olmasına ve yerli halkın da dış ülkelerle sürekli olarak ticari faaliyetlerde bulunmasına sebep olmuştur. Dolayısıyla İzmir şehri salgın hastalıkların ülkeye adeta giriş kapılarından biri haline gelmiştir.

1307/1889-1890 ve 1326/1908-1909 yıllarına ait Aydın vilayet salnameleri dönemin demografik yapısı hakkında bilgi veren önemli kaynaklardandır. Bu kaynaklara göre 1307/18891890 yıllarında İzmir Sancağında yerli kadın nüfusu 225.303, yabancı kadın nüfusu ise 11.187'dir. Burada toplam kadın nüfusu ise 236.490 kişidir. Bu yıllarda İzmir kazasının yerli kadın nüfusu 86.020, yabancı kadın nüfusu ise 10.063'tür. Kazanın toplam kadın nüfusu 96.083 kişidir (Salnamei Vilayet-i Aydın, 1307: 403). 1326/1908-1909 Aydın Vilayet Salnamesinin nüfus verilerine göre İzmir Sancağın da bulunan yerli kadın sayısı 288.899'dur. Sancaktaki yabancı kadın sayısı ise 15.885 'tir. Bu yılda şehirdeki toplam kadın nüfusu ise 304.784'tür (Salname-i Vilayet-i Aydın, 1326:760). 


\section{İzmir'de Frengi Hastalığının Ortaya Çıkışı ve Alınan Önlemler}

İzmir'in tarihinde salgın ve bulaşıcı hastalıklar önemli bir yer tutmaktadır. Şehirde görülen bu hastalıklar nüfusta büyük kayıplara sebep olurken binlerce kişinin ölümüne yol açmıştır (Baykara, 2001: 110). Bu bölgede daha ziyade bahar ve yaz aylarında ortaya çıkan salgın hastalıklar, sağlık kuruluşlarının da yetersiz olması sonucunda önemli sorunları beraberinde getirmiştir (Beyru, 2005:79). Önemli salgın hastalıklardan birisi olan frengi ise İzmir'de 1889 ve 1890 y1llarında ilk kez bölgesel olarak görülmeye başlamıştır. Daha sonra 1893, 1901,1902 ve 1904 yıllarında hastalık şehirde salgın niteliğinde sürmeye devam etmiştir. Özellikle XX. yüzyılın başlarında kentte eğlence ve fuhuş artış göstermiştir. Frengi hastalığının kentte yayılmasının başlıca sebebi Rum genelevleridir. $\mathrm{Bu}$ dönemde en popüler Rum genelevleri, Maison Doree ve Madam Eme'nin işletmeleri idi. İkinci Kordon'da bulunan Osmanlı Postanesi'nden Cafe Costi civarına çıkan sokakta lüks olarak nitelendirilen genelevler yer almıştır. Alsancak Garı civarı, Mersinli, Bayraklı gibi yerleşim yerlerinde ise ikinci sınıf genelevleri faaliyette idi. Kemer mevkiinde ise çoğunlukla üçüncü sinif umumhaneler bulunuyordu (Ocak, 2016: 23-25).

Bu dönemde hastalığın önlenmesi için hükümet sürekli olarak gerekli tedbirleri alma yoluna gitmiştir. İzmir Valisi Halil Rıfat Paşa 7 Kasım 1889 tarihinde Dâhiliye Nezaretine konuyla ilgili bir rapor göndermiştir. Bu raporda Sıhhiye Müfettişi, Askeri Hastanenin başhekimi ile Gureba-i Müslimin Hastanesi'nin Başhekimi Mustafa Enver Bey'den oluşan Sihhiye Komisyonu'nun hazırlamış olduğu frengi ile mücadele hususunda on maddeden oluşan önerileri yer almaktadır. Frengi hastalığı ile mücadele için alınacak tedbirleri ve uygulamaları içeren söz konusu raporda özetle şöyle denilmektedir:

1-Frengi hastalığının asıl kaynağı umumhanelerdir. İzmir'in var olan deniz ve karayolları şehre ulaşımı kolaylaştırdığı için hastalığın hızla yayılmasını sağlamıştır. Bu sebeple frengi için önlemler biran evvel alınmalıdır.

2- Hacı Bey Hanı mevkiinde ve Kordon civarındaki genelevler Sakızlar Mahallesi'ne kaldırılmalıdır. Buradaki hayat kadınlarının muayenesi aralıksız bir şekilde sıhhiye müfettişinin denetiminde iki veya üç doktordan oluşan bir komisyonla yapılmalıdır. Ayrıca hastalığa yakalanmış kişilerin tedavileri için 25 yataktan oluşan bir hastane açılmalıdır.

3- Hayat kadınları haftanın cumartesi ve pazar günleri muayene edilmelidir. Muayene sonrası frengi hastalığı görülen kadınlar hastaneye, hastalık görülmeyenlerin sağlam raporları ise hastane müdürlüğüne gönderilmelidir. Genelev işletme sahipleri bu prosedürleri yerine getirmekle sorumlu tutulmalidır.

4-Hastalığa yakalanmayan kişileri belirtmek için boyunlarına bir madalyon ve muayene edildiğini gösteren bir kurdele takılmalıdır.

5-Hayat kadınlarının muayenesini yapan doktor hastalığa yakalanan kişiyi iyileşmeden taburcu etmek veya gerçek olmayan bir rapor hazırlamak gibi davranışlarda bulunursa veya görevini layıkıyla yapmazsa görevden alınıp cezalandırılmalıdır.

6-Sakızlar Mahallesi’nde 71 adet genelev bulunmakta ve 280 hayat kadını çalışmaktadır. $\mathrm{Bu}$ hanelerden hastane masraflarını karşılamak için 1.345 lira para toplanmalıdır.

7-Hastane giderleri ve çalışanlar için toplanan paralar belediye sandığına teslim edilmelidir. Polis memuru ve bir belediye çavuşu paraların tahsili için görevlendirilmelidir. Hastane müdürü, iki doktor, eczacı ve hademe maaşları ile kira giderleri için toplam 275 adet Sim Mecidiyeye gerek vardır. Ayrıca yiyecek, giyecek vb. ihtiyaçlar için de 385 Mecidiyeye gereksinim duyulmaktadır. Harcanılacak paralar hastane komisyonu tarafindan bir tutanakla düzenlenmeli ve Sihhiye Komisyonu tarafından onaylanmalıdır. 
8- İki doktordan biri nöbet usulüyle geneleve gidip hayat kadınlarını muayene etmelidir. Gerektiği zamanlarda iki doktor birlikte hem hastanede hem de genelevlerde hekimlik yapmalıdır.

9-Toplanılan paralar sadece genelevlerde ortaya çıkan bulaşıcı hastalıkların tedavisi için kullanılmalı, artan paralar ise gelecekte hastane inşaatı için saklanmalıdır.

10-Sihhiye Komisyonu bu maddelere uyulduğu takdirde frengi hastalığının ortadan kalkacağını düşünmektedir (Ocak, 2016: 41-42).

\section{İzmir'de Frengi Hastalığıyla Mücadele ve Umumhaneler}

XIX. yüzyılın son zamanlarında giderek artış gösteren frengi hastalığının şehirde hızla yayılmasının başlıca sebebi olarak, yukarıda da belirtildiği üzere umumhane işletmeleri gösterilmiştir (Karayaman, 2008: 178). İzmir'de anneler yetişkin erkek çocuklarının genelevlere gitmelerine izin verirlerdi. Aileler kız çocuklarının evlenirken bakire olmasına önem verirlerken, erkek çocuklarının ise umumhanelerde cinsel tecrübe kazanmasında sakınca görmemektelerdi. Bununla birlikte evlenmek isteyen genç erkeklerin yeterli maddi imkânları bulunmaması sebebiyle evliliği gecikmekte ve bu durumun sonuçlarından biri olarak da şehirde fuhuş giderek yaygınlaşmaktaydı (Georgelin, 2008: 162). Ayrıca savaşın getirmiş olduğu ekonomik sıkıntı sebebiyle de kadınlar geçimlerini sağlamak için fuhuş sektörüne yönelmek zorunda kalmışlardır.

İzmir'in en işlek ticaret merkezleri olan İkinci Kordon, Osmanlı Postanesi ve Maltızlar mahallesi şehrin umumhanelerinin bulunduğu mevkilerdir (BOA,1327). Dâhiliye Nezareti bu yerlerin işlek olması ve bölge halkının da hoşnutsuzluğu sebebiyle umumhanelerin bulunduğu yerden kaldırılarak daha münasip bir mahalleye nakledilmesi için teşebbüste bulunmuştur (BOA, 1327). Nitekim bu umumhaneler Punta'nın mabetler, mektepler ve kabristan civarına nakledilmişlerdir. Ancak işletme sahipleri bu durumun Kanun-i Esasi'nin şahsi hürriyete, mesken ve mekân dokunulmazlığına aykırı olduğu gerekçesiyle itiraz etmişler ve işletmelerinin eski yerlerinde kalması hususunda Dâhiliye Nezaretine itirazda bulunmuşlardır. Bu itirazlar üzerine Dâhiliye Nezareti konuyu Şura-yı Devlet'e havale etmiştir. 1327 yılında Şura-yı Devlet Mülkiyesi tarafından hazırlanan mazbatada, Punta'daki mabet, mektep ve kabristan civarına nakledilen umumhanelerin oradan kaldırılarak başka bir yere nakledilmesi gerektiği belirtilmiştir. Çünkü umumhanelerin mabetlere yakın olması ayin yapılmasını, mekteplere yakın olması ise bu mekteplerde okuyan çocukların ahlaki yönlerini olumsuz etkileyeceğinden bu mevkilerde bulunması uygun görülmemiştir. Ayrıca dükkân sahipleri de burada bulunan umumhanelerden dolayı insanların alışveriş yapmaya gelmemelerinden şikâyet etmişlerdir. Alınan karar doğrultusunda İkinci Kordon civarı ve mahalle araları gibi yerlerden gizli umumhanelerin kapatılıp bu işletmelerin şehir dışındaki Sakızlar Mahallesine nakledilmesine karar verilmiştir (BOA,1327). Ancak "Kedi" ve "Estasiye" isimli kadınların işlettiği umumhaneler hala Sakızlar mevkiine taşınmamış ve faaliyette bulunmaya devam etmiştir. Bu durumdan rahatsız olan İzmir halkından Salih Müslim adında bir vatandaş Dâhiliye Nezareti'ne konuyla ilgili dilekçe vermiştir (BOA, 1328). Dilekçede söz konusu problem şu şekilde dile getirilmiştir:

"Dâhiliye Nezaret-i Aliyesine"

“Nefs-i İzmir'in İkinci ve Üçüncü Kordon cihetlerindeki mevcut umumhanelerin birkaçında hatta Roko (Roka)Kârhanesi'nde Kedi namında bir umumhane sahibesi ile civarındaki Taşçılar mevkiinde Estasiye'nin umumhanesinde bir takım genç çocuklar bulundurularak türlü türlü efal-ı gayr-ı layıka ve şenia vukua gelmektedir. Bu cihet polis memurlarının bile malumatı tahtındadır. Gerek bu fenalıkların gerek böyle şeyn dâhilinde umumhanelerin mevcut bulunması birçok fenalıklara sebebiyet vermekten başka şehrin en mutena bir mevkiinde umumhanelerin mevcudiyeti bütün o güzel mevkiin şerefini ihlal ve ibtal etmekle beraber hariçten gelecek olan ecanibin ilk nazarda tesadüf edecekleri işbu umumhaneler ve çirkin manzaralar olacağından İzmir şehri için bunun hakikaten şeyn olduğu muhtac-ı izah değildir. Bir de bu umumhanelerde böyle mahallerden 
ref'i ile esasen umumhane ittihaz edilen Sakılar Mahallesi'ne nakli vaktiyle nezaret-i Aliyelerinden emir verilmiş ve ekserisi kaldırılmış iken her ne sebebe mebni ise ahiran bunların ibka ve küşadına müsaade olunmuş olduğundan selamet-i umumiye namına emr-i mezkûrun ifa ve infazı içün tekrar emir verilmesi müsterhamdır efendim hazretleri" (BOA,1328).

Polis Nizamnamesi'nin 82. maddesine göre alınan bir kararla genç kimseleri adaba ve ahlaka aykırı davranmaya sevk eden meyhane, genelev gibi işletmeler hakkında kanuni işlem yapılacağı bildirilmiştir (BOA, 1328). İzmir'de şiddetli görülen frengi hastalığını defetmek için özel hastanelerin kurulması gerektiğine karar verilmiştir (BOA,1308). Hayat kadınlarının tedavisi için yapılacak bu hastanenin masraflarının şehirdeki genelevlerden karşılanması uygun bulunmuştur (BOA,1308). İzmir hekimlerinden olan Marinu Kotovali tarafindan 1889 y1lında ilk kez bir frengi hastanesinin açılışı gerçekleştirilmiştir (Ahenk Gazetesi, 28 Eylül 1899). Ancak bu hastanenin bakımsız ve temiz olmadığı yönünde bazı iddialar ortaya atılmıştır. Umum Mekatib-i Askeriye-i Şahane Nezareti durumdan haberdar olup bu hastanenin kapatılıp yerine daha büyük ve donanımlı bir zührevi hastalıklar hastanesinin açılması gerektiğini Valilik ve İl Sihhiye Müfettişliğgine yazılı olarak bildirmiştir. Ancak hastane kapatılmayıp 1908 yılında bile hala faaliyetlerini sürdürmeye devam etmiştir (Ocak,2016: 46). Yeni bir hastane inşasının temelleri ise1907 yılında atılmıştır. Frengili hayat kadınlarını tedavi etmek için 1908 yılında Tepecik semtinde Emraz-1 Zühreviye Hastanesi'nin (Frengi Hastanesi) açılışı gerçekleştirilmiştir (Karayaman, 2008:179). Hastane ilk zamanlarda belediyeye bağlı iken 1913 yılında idaresi bir komisyona devredilmiştir (Ocak-Kocabaş, 2016: 28). Bu tarihten itibaren Emraz-1 Zühreviye Hastanesi'nin (Frengi Hastanesi) ismi kuruluşunda emeği geçen eski belediye başkanı olan merhum Eşref Paşa'nın adını almıştır (Ahenk Gazetesi, 4 Aralık 1913: 2).

XIX. yüzyılın sonlarına doğru İzmir basınında frengi hastalığına ilişkin çeşitli haberlere yer verilmiştir. Gazetelerde hastalığın Avrupa'dan Anadolu halkına yayıldığı ve bu hastalığın ölümden bile kötü olduğu, hastalığın yalnız kişinin kendisini değil tüm ailesini etkilediği vurgulanmıştır (Bulut, 2009: 113). Ayrıca hastalığın yayılma sebepleri, tedavi yöntemleri, hastalıkla ilgili alınan veya alınması gereken önlemler gibi konular da gazete haberlerinde yer almıştır. Örneğin frengi hastalığıyla ilgili basına yansıyan önemli konulardan birisi Frengi Hastanesiyle ilgilidir. Haberde hastane için yeni bir nizamname hazırlığı yapıldığından ve bunun gerçekleştirilmesi için özel bir komisyon oluşturulduğundan ve konuyla ilgili toplantılar gerçekleştirildiğinden bahsedilmiştir (Ahenk Gazetesi, 8 Ekim 1913:2). Frengi Hastanesi’nin yönetiminde meydana gelen değişiklik de gazete haberlerine konu olmuştur. Haberde hastanenin vilayet kanunu gereğince özel bir komisyon tarafından idare edilmeye başlandığı yazmaktadır (Ahenk Gazetesi, 29 Ekim 1913: 2). İl Özel İdaresi de hastanenin masraflarının karşılanmasını ve yönetimini üstlenmiştir (Ahenk Gazetesi, 26 Ekim 1913: 2).

Ahenk Gazetesi'nin başyazarı olan Şinasi de okuyucuları hastalıkla ilgili bilinçlendirmek için frengi hastalığının ciddi derecede tehlikeli olduğunu vurgulayan ve Frengi hastanesi için maddimanevi her türlü yardımın yapılması gerektiğini konu alan bir makale yayınlamıştır (Ahenk Gazetesi, 11 Aralık 1913: 2). İzmir'de frengi hastalığının görüldüğü tarihlerde kolera salgınları da yaşanmıştır. Hatta yaşanan kolera salgınları Frengi Hastanesini de etkilemiş ve hastane geçici bir süre koleralı hastaların tedavisinde kullanılmıştır. Frengi Hastanesi'nde tedavi gören hastalar ise Gureba Hastanesine nakledilmişlerdir. Kolera salgınlarının azalmasıyla gerekli temizlik işlemleri yapıldıktan sonra frengili hastalar tekrar Frengi Hastanesine alınmışlardır (Ahenk Gazetesi, 7 Kasım 1913: 2). Frengi hastalığını tedavi eden doktorların reklamları da gazete haberlerine yansımıştır. Örneğin; "Doktor Cevdet" başlığıyla yer alan ilgili haber dikkat çekicidir:

"Doktor Cevdet, Frengi, belsoğukluğu, kadın ve erkek tenasülü ve bevlî hastallklar mütehassist ve Eşrefpaşa Frengi Hastanesi Sertabibi yeni ve eski belsoğukluğu, idrar zorluğu, ademi iktidar, seyelan-ı meni, kesret-i ihtilam, rahim, böbrek ve cilt hastalıklarını muvaffakyetle tedavi 
eylediği gibi frenginin her şeklini en son usuller ile zerk etmek suretiyle az müddetle kemal-i muvaffaklyetle tedavi eyler. Her gün öğlenden sonra alafranga saat 1-2'ye ve 4-5'e kadar Kemeraltında (Şifa) Eczanesi'ne müracaat edenleri kabul ve tedavi eyler. Fukaraya cuma günü meccanen (Ahenk Gazetesi, 30 Ocak 1914: 2)”.

Görüldüğü üzere salgın hastalıkların yaşandığı süreçte gazeteler okuyucuları bilgilendiren önemli araçlardan biri olmuştur. Çalışmamızda yararlandığımız ve dönemin İzmir basınında önemli bir yer tutan Ahenk gazetesi nüshalarında da Frengi hastalı̆̆ıla ilgili halkı bilinçlendirmek adına haberlere yer verilmiş, böylelikle toplumun frengi salgınıyla baş edebilmesi için kamuoyu sürekli biçimde bilgilendirilmiştir.

\section{Sonuç}

İnsanlığın varoluşundan itibaren dünyanın hemen hemen her bölgesinde görülen salgın hastalıklar binlerce insanın ölümüne yol açmıştır. Büyük yıkımlar yaratan bu hastalıklar Osmanlı Devleti topraklarında da görülmüştür. Osmanlı Devleti kurulduğu tarihten itibaren insan sağlığına gereken önemi vermiştir. Eski dönemlerde hastalıkların önlenmesi için geleneksel tıp metotları uygulanmış ancak bu yöntemler hastalıklarla başa çıkma hususunda yetersiz kalmıştır. Osmanlı topraklarında veba, kolera, tifüs, verem, trahom, çiçek, tifo, kuduz, sıtma gibi hastalıklar mevcut olup, frengi bu hastalıkların içerisinde önlem alınmadığı takdirde en tehlikeli salgın hastalıkların başında zikredilmiştir. Fuhuş ise bu hastalığın yayılmasındaki en önemli etken olmuştur. Fuhuş Osmanlı'nın hemen her döneminde mevcut olan bir eğlence anlayışı olup, Kırım Savaşı sonrasında artı̧̧ göstermiştir. Bu faaliyetlerin yaygınlık kazanmasıyla birlikte frengi vakaları da oldukça artmıștır. Bu sebeple hükümet fuhuş problemini kontrol altına almak için umumhanelerin açılmasına göz yummuştur. Hükümetin buradaki amaçlarından biri fuhuş faaliyetlerini belirli bir mekânda denetim altında tutarak cinsel yolla bulaşabilecek hastalıkların önüne geçmektir. Çünkü fuhuş sorununu tamamen engellemek veya azalmasını sağlamak neredeyse imkânsızdır. Şehirlerde kontrol altında tutulan umumhane işletmelerinin aç1lışı ve buraların denetimi için resmi görevliler bulundurulması fuhşun bir bakıma yasal bir çerçevede ele alınmasını sağlayarak devlet kontrolünü mümkün kılmıştır.

Kozmopolit bir yapıya sahip olan İzmir, Türklerin, Rumların, Ermenilerin, Yahudilerin, Levantenlerin ve Zencilerin yaşadığı bir liman şehri olmuştur. Farklı din ve millete mensup olan bu söz konusu unsurlar İzmir'in sosyal hayatını şekillendirme hususunda önemli bir yere sahip olmuş ve bu toplulukların yaşayış biçimlerindeki farklılıklar Müslümanlar üzerinde zamanla etkisini hissettirmeye başlamıştır. Çeşitli etnik grupları içinde barındıran İzmir şehrinde özellikle I. Dünya Savaşı yıllarında fuhuş faaliyetlerinde belirgin bir artış görülmüştür. Savaş ortamının getirdiği işsizlik ve sefalet kadınların geçimlerini sağlamak için fuhuş sektörüne yönelmelerine neden olmuştur. Umumhanelerde çalışan kadınların çoğunluğunu Gayri-müslim tebaa oluştururken, az sayıda Müslüman kadın da bu işletmelerde çalışarak geçimlerini sağlamışlardır.

Zührevi hastalıklardan biri olan frengi, dönemin basınında sıkça adından söz ettiren hastalıklardandır. Gazetelerde frengi hastalığının ne kadar tehlikeli olduğundan, kişiye bulaşması durumunda ailesinin de bu hastalıktan zarar görebileceğinden, şehre hızla yayıldığından ve bunun önlenmesi için genelevlerin düzenli olarak sağlık kontrolünden geçmesi gerektiğinden söz edilmiştir. Diğer taraftan bu hastalığın yayılmaya başladığı ilk zamanlarda tam bir uzmanlaşma söz konusu değildir. İlerleyen zamanlarda fuhuş olaylarının denetim altına alınması için hükümet birtakım faaliyetlerde bulunmuştur. Öncelikle Kordon civarındaki mahalle aralarında bulunan gizli umumhanelerin kaldırılıp bunların şehir dıșındaki Sakızlar Mahallesi'ne nakledilmesi istenmiștir. Bu işletmelerde çalışan kadınların sağlık kontrollerinin düzenli olarak yapılması ve sürekli denetim altında tutulması kararı alınmıştır. Bu şekilde şehirde fuhuş denetim altında tutulmuş ve frengi salgınlarının yayılması önlenmeye çalışılmıştır. Ancak bu hastalığın önlenmesi için yeterli bir uygulama olmamıştır. Bu sebeple frengi hastalığıyla mücadele hususunda yapılan en önemli 
faaliyetlerden biri İzmir'de Frengi Hastanesinin inşası ve daha da önemlisi frengi hastalığının tedavisi için 606-Salvarsan adlı ilacın keşfedilmesi olmuştur.

Nitekim Frengi hastalı̆̆ı, XIX. yüzyılın sonlarında İzmir şehrinde etkisini kuvvetli bir şekilde hissettirmiş ve şehirdeki salgını önlemek için çeşitli önlemler alma yoluna gidilmiştir. Alınan önlemler frengi hastalığının geçici olarak denetim altına alınmasını sağlamasına rağmen frengi salgınları Cumhuriyet döneminde de varlığını sürdürmüştür. Ancak II. Dünya Savaşı sonrasında frengi hastalığı artık eski tehlikesini yitirmiş ve nihayet tedavisi mümkün bir bulaşıcı hastalık haline gelmiştir.

\section{Kaynakça}

\section{Arşiv Kaynakları}

BOA, DH. MUI, 92/14, 26 Nisan 1328/ 9 May1s 1912

BOA, DH.MKT, 2763/52, 17 Şubat 1327/ 1 Mart 1912

BOA, DH.MKT, 2735/84, 18 Ocak 1327/ 31 Ocak 1912

BOA, DH. İ, 46/82, 16 Mayıs 1331/ 29 Mayıs 1915

BOA, DH.MKT, 1838/66, 24 Ekim 1308/ 5 Kasim 1892

BOA, A. MKT. M.HM, 502/23, 26 Aralık 1308/ 7 Ocak 1893

BOA, DH. MKT, 1689/ 118, 22 May1s 1327/ 4 Haziran 1911

\section{Süreli Yayınlar}

Ahenk Gazetesi

\section{Salnameler}

Salname-i Vilayet-i Aydın, 1307 (1891-1892), Vilayet Matbaası, 1307.

Salname-i Vilayet-i Aydin 1326, Vilayet Matbaas1, 25. Defa.

\section{Kitaplar}

Baykara, T. (2001), İzmir Şehri ve Tarihi, Akademi Kitabevi.

Beyru, R. (2000), 19. Yüzyılda İzmir'de Yaşam, Literatür Yayıncılık.

Georgelin, H. (2008), Smyrna'nın Sonu İzmir'de Kozmopolitizmden Milliyetçiliğe, Çev: Saadet Özen, Birzamanlar Yayınc1lı.

Karayaman, M. (2008), 20. Yüzyılın İlk Yarısında İzmir'de Sağlık, İzmir Büyükşehir Belediyesi Yayını.

Ocak, B., Kocabaş, Ö. (2016), İzmir Gureba-i Müslimin Hastanesi’nden İzmir Devlet Hastanesine "Bir Hastane Öyküsü", İzmir Büyükşehir Belediyesi Yayını.

Ocak, B. (2016), Halk Sağglı̆̆ Hizmetinde 107 Yll İzmir Büyükşehir Belediyesi Eşrefpaşa Hastanesi, İzmir Büyükşehir Belediyesi Yayını.

Sami, Ş. (1996), Kamusü’l Alam, Kaşgar Neşriyat.

Sürgevil, S. (2009), II. Meşrutiyet Döneminde İzmir, İzmir: İzmir Büyükşehir Belediyesi Kültür Yayın1. 


\section{Makaleler}

Bulut, F. (2019), “Osmanlı'dan Cumhuriyet'e Tehlikeli Bir Miras: Frengi”, Tarih Okulu, S: 3, s. 109123.

Çavdar, N., Karcı, E. (2016), "XIX. Yüzyıl Sonları XX. Yüzyılın Başlarında Osmanlı Devleti’nde Frengi ile Mücadele Kapsamında Yapılan Yasal Düzenlemeler", Gaziosmanpaşa Üniversitesi Sosyal Bilimler Araştırmaları Dergisi, s.157-175.

Esiner, M. A. (2018, 19-20-21 Nisan), The Turks In The Eyes Of A Brittsh Woman Traveller In 19th Century. I. Uluslararası Türk Kültürü ve Tarihi Sempozyumunda sunuldu. İstanbul.

Gözcü, A. (2016), “I. Dünya Savaşı ve Osmanlı Devleti'nin Gündelik Hayatından Kesitler”, Çağdaş Türkiye Tarihi Araştırmaları Dergisi, XVI/32, s. 133-169.

Hot, İ. (2015), “Tanzimat Sonrası Osmanlı'da Bulaşıcı Hastalıklarla Mücadele”, Osmanlı'da Salgın Hastalıklarla Mücadele, Ed. İbrahim Başağaoğlu, Ahmet Uçar, Çamlıca Yayınları, s. 113150.

Kırlı, E. (2010), "Tanzimat Sonrası Fuhuş Hadisesine Yaklaşımda Yaşanan Değişim”, Süleyman Demirel Üniversite Sosyal Bilimler Enstitüsü Dergisi, S:12, s. 39-51.

Kütükoğlu, M. (2006), “İzmir”, Türkiye Diyanet Vakfi İslam Ansiklopedisi, Cilt 23: s. 515-524.

Martal, A. (2000), "Illet-i efrenciye (İzmir'de Frengiyle Mücadele)", Tepekule Tarih Yerel Tarih Araştırmaları Dergisi, S: 1, s. 88-91.

Özcan, A. (2003, 23-25 Mayıs), Kırım Savaşı’nda Üsküdar ve Ingiliz Askerleri. Üsküdar Sempozyumunda sunuldu.

Rothschild, B. M. (15 Mayıs 2005), "History Of Syphilis". Clinical Infectious Diseases: An Official Publication Of The Infectious Diseases Society Of America. 40 (10) s.1454-63.

Şenel, D. (2015), “19. Yüzyılda Kastamonu Vilayetinde Frengi Hastalığıyla Mücadele”. Celal Bayar Üniversitesi Sosyal Bilimler Dergisi, 13 (1) s. 256-274.

Yıldırım, N. (1985), “Tanzimat'tan Cumhuriyet'e Koruyucu Sağlık Uygulamaları", Tanzimat'tan Cumhuriyet'e Türkiye Ansiklopedisi, C: 5, İletişim Yayınları, s. 1320-1338. 